\title{
GENETIC COMPARISONS OF GERMAN POPULATIONS OF THE STONE CRAYFISH, AUSTROPOTAMOBIUS TORRENTIUM (CRUSTACEA: ASTACIDAE)
}

\author{
C.D. SCHUBART and M.G.J. HUBER
}

Biologie 1: Institute of Zoology; University of Regensburg; D 93040 Regensburg,
Germany. E-Mail: Christoph.Schubart@biologie.uni-regensburg.de

Reçu le 23 juin 2005

Received June 23, 2005

Accepté le 14 janvier 2006

Accepted January 14, 2006

\begin{abstract}
Austropotamobius torrentium (SCHRANK, 1803) is the smallest of the European native crayfish species and has probably never been of economic interest. It is confined to headwaters and adapted to cold water with high flow through and rocky environments. These properties make the stone crayfish a useful species for population genetics and phylogeographic studies. Representatives were collected from 18 localities throughout southern Germany and analysed with two mitochondrial genetic markers. Initial results revealed that German populations of $A$. torrentium from the Danube and Rhine tributaries share identical haplotypes in 528 basepairs of $16 \mathrm{~S}$ rRNA and 658 basepairs of the COI gene. Rare haplotypes of the COI genes were occasionally encountered and apparently restricted to southwestern Bavaria. Only three variable sites were found over a length of 658 basepairs in 45 German, Swiss and Austrian stone crayfish resulting in five different haplotypes, with the prevalence of one most common haplotype. Here we show that in German populations rare haplotypes are not randomly distributed, but found in higher frequencies in the Bavarian Alps of the Allgäu and in adjacent Tyrol. On the other hand, stone crayfish population from the Bavarian Forest and the Rhine tributaries appear genetically impoverished, so far only showing the most common haplotype. Consequently, there are significant differences between the Allgäu populations and the rest of the German populations in haplotype frequencies, resulting in a relatively high $F_{\mathrm{ST}}$ value. This finding is of importance for future conservation efforts of stone crayfish populations in Germany and Austria.
\end{abstract}

Key-words: Astacidae, gene flow, bottleneck, conservation genetics.

\section{COMPARAISONS GÉNÉTIQUES DE POPULATIONS ALLEMANDES D'ÉCREVISSE DES TORRENTS, AUSTROPOTAMOBIUS TORRENTIUM (CRUSTACEA: ASTACIDAE)}

\section{RÉSUMÉ}

Austropotamobius torrentium (SCHRANK, 1803) est la plus petite des espèces d'écrevisses natives d'Europe et n'a probablement jamais eu d'intérêt économique. Elle est confinée au cours supérieur des rivières et est adaptée aux eaux froides à fort courant et avec un environnement rocailleux. Ces propriétés font de l'écrevisse des torrents une espèce utile pour les études de génétique des populations et de phylogéographie. Des échantillons ont été prélevés dans 18 localités réparties dans toute le Sud de l'Allemagne, puis analysés avec deux marqueurs génétiques mitochondriaux. Les premiers résultats 
ont montré que les populations allemandes d'A. torrentium des affluents du Danube et du Rhin ont le même haplotype pour une séquence de 528 paires de bases d'ARNr 165 et pour une séquence de 658 paires de bases du gène COI. Des haplotypes rares du gène $\mathrm{COI}$ ont été occasionnellement rencontrés, cantonnés apparemment dans le Sud de la Bavière. Parmi 45 écrevisses des torrents d'Allemagne, de Suisse et d'Autriche, seuls trois sites variables ont été trouvés sur une longueur de 658 paires de bases, conduisant à cinq haplotypes différents parmi lesquels prévaut un haplotype très répandu. Ici nous montrons que dans les populations germaniques, les haplotypes rares n'ont pas une distribution aléatoire mais se trouvent en fréquence plus élevée dans les Alpes bavaroises de l'Allgäu et dans le Tyrol adjacent. D'un autre côté, les populations d'écrevisse des torrents de la Forêt Bavaroise et des affluents du Rhin semblent tellement appauvries génétiquement qu'elles ne présentent que l'haplotype commun. Par conséquent, il y a des différences significatives entre les populations d'Allgäu et le reste des populations allemandes au niveau de la fréquence des haplotypes, conduisant à un $F_{\mathrm{ST}}$ relativement élevé. Ce résultat est important pour les mesures de conservation à venir des populations d'écrevisse des torrents en Allemagne et en Autriche.

Mots-clés: Astacidae, flux génique, goulot d'étranglement, génétique de la conservation.

\section{INTRODUCTION}

In recent years, a number of population genetic studies on the European white clawed crayfish, Austropotamobius pallipes sensu lato, have received a lot of attention. The studies by GRANDJEAN et al. (2000a, 2000b, 2002a, 2002b), FRATINI et al. (2005) and TRONTELJ et al. (2005) revealed that this species complex probably has its centre of radiation (and found its Pleistocene refugia) in Istra (Croatia) and Italy, where five distinct genetic forms can be recognized, which are in part referred to as separate species or subspecies: A. pallipes (Lereboullet, 1858) and A. italicus (Faxon, 1914), the second possibly consisting of the subspecies italicus, carsicus, carinthiacus, and meridionalis (GRANDJEAN et al., 2002b; FRATINI et al., 2005, discussed by TRONTELJ et al., 2005). On the other hand, the genetic diversity of this crayfish from the British Isles, Ireland and Spain is comparatively impoverished and the latter two faunas probably represent more or less recent human-mediated introductions from Italy into Spain, (ALBRECHT, 1983; GRANDJEAN et al., 2000b) and from France into Ireland (GOUIN et al., 2001). These results are of crucial importance for conservation biology, because they allow discerning the areas with the highest genetic richness within this species complex and determining which populations should be given highest priority in terms of conservation measurements (e.g. GRANDJEAN and SOUTY-GROSSET 2000; FRATINI et al., 2005).

The second species of Austropotamobius, the stone crayfish A.torrentium (SCHRANK, 1803) is also an entirely European form. It is confined to headwaters and small water systems, adapted to water with turbulent flow through and rocky environment (HUBER and SCHUBART, 2005). A. torrentium shows a distribution with almost no overlap with the western European $A$. pallipes complex, and ranges from eastern France and Luxembourg, throughout southern Germany, northern Switzerland, Austria and northeastern Italy, far southeast from Slovenia and Croatia into the Balkans all the way into northern Greece, Bulgaria and into Black Sea Turkey.

Until very recently, there had been no published results dealing with intraspecific genetic diversity and heterogeneity within the stone crayfish. During the Craynet Meeting in Innsbruck 2004 we reported on the genetic homogeneity (16S rRNA and COI genes) of stone crayfish in German populations from Rhine and Danube (HUBER \& SCHUBART, 2004). More recently, a paper by TRONTELJ et al. (2005) documented high overall genetic 
diversity in A.torrentium based on 585 basepairs of the cytochrome oxidase subunit I gene (COI), especially in southeastern Europe. This phylogeographic study reveals that genetic distances between a crayfish population in the Kolpe region (situated between Croatia and Slovenia) and other stone crayfish populations are almost as pronounced as those between typical $A$. torrentium and $A$. pallipes. This suggests that $A$. torrentium, as currently considered, has also to be regarded as a species complex. However, the study by TRONTELJ et al. (2005) also showed that in its northwestern distributionary limits (Rhine tributaries and southeastern slopes of the Alps draining into the Danube), A. torrentium is characterised by a large number of different haplotypes, which are very closely related.

In the present study, we carry out a population genetic analysis complementing the phylogeographic results by TRONTELJ et al. (2005) by including a much wider range of German populations (Rhine tributaries and Danube tributaries north of the Alps), a larger number of individuals and a slightly longer fragment of the COI gene. We address the question, whether haplotype frequencies and the potential accumulation of rare haplotypes in some of the German populations can demonstrate lack of gene flow and reveal, which geographical areas may harbour the highest genetic diversity of the German stone crayfish populations. This would allow to designate centres of priority for the conservation of this protected species.

\section{MATERIAL AND METHODS}

Between 2002 and 2004, stone crayfish were collected from 18 localities throughout southern Germany (see HUBER \& SCHUBART, 2005), one locality from Haldensee (Tyrol, Austria; see MACHINO \& FÜREDER, 1998) and one near Logatec (Slovenia) (see MACHINO, 1997). Our sampling activities included three tributaries from the Rhine system: Bodensee near Konstanz (Lake Constance), Schwarzwald near Freiburg (Black Forest) and Odenwald near Heidelberg; plus 15 populations from the Danube system. Most collections were carried out in Bavaria and more specifically in the surroundings of Regensburg in the western Bavarian Forest, as well as in the Allgäu in the western German Alps (all Danube catchment) (see Figure 1 in HUBER \& SCHUBART, 2005). In addition, DNA sequences were obtained from preserved specimens of the Senckenberg Museum in Frankfurt (SMF) collected in the Taunus (central Germany, SMF 22624), Wienerwald (eastern Austria, SMF 15336) and Sandanska Bistrica (southwestern Bulgaria, SMF 13185). Tissue from two populations from northern Switzerland (Thurgau) in the vicinity of the Bodensee and thus belonging to the Rhine catchment were kindly provided by Carlo Largiadèr.

Genomic DNA was extracted from the muscle tissue of a walking leg, or in smaller specimens from the abdomen, using the Puregene kit (Gentra Systems). A total number of 45 specimens from southern Germany, Switzerland and Austria were thereby genetically examined (10 in the case of 16S). Three specimens from Slovenia and two from Bulgaria served as outgroup for both genes. The selective amplification of a 528 basepair fragment from the large subunit rRNA (16S) and a 658 basepair fragment from the cytochrome oxidase subunit I (COI) genes (in both cases excluding primers) was carried out by polymerase chain reaction (PCR) $\left(40\right.$ cycles; $45 \sec 94^{\circ} \mathrm{C} / 1$ min $48^{\circ} \mathrm{C} / 1$ min $72^{\circ} \mathrm{C}$ denaturing / annealing / extension temperatures) with the primers 16L2 (5'-TGCCTGTTTAT-CAAAAACAT-3'), and 1,472 (5'-AGATAGAAACCAACCTGG-3') (see SCHUBART et al., 2002) for the 16S gene and LCO1490 (5'-GGTCAACAAATCATAAAGATATTGG-3') (FOLMER et al., 1994), COL6b (5'-ACAAATCATAAAGATATYGG-3'), COH6 (5'-TADACTTCDGGRTGDCCAAARAAYCA-3') and $\mathrm{COH} 17$ (5'-GTATTTAAATTACGATCTGTTA-3') (newly designed; first two based on FOLMER et al., 1994) for the COI gene. The PCR products were purified with Millipore Montage PCR Centrifugal Filter Devices (Millipore, Corp). The products were precipitated with ethanol, resuspended in water and sequenced with the ABI BigDye terminator mix (Big Dye Terminator ${ }^{\circledR}$ v 1.1 Cycle Sequencing Kit; Applied Biosystems) in an ABI Prism 
automated sequencer (ABI Prism ${ }^{\mathrm{TM}} 310$ Genetic Analyzer). The sequences were analysed with the program $A B I$ Sequencing Analysis $₫ 3.4$ (Applied Biosystems) and manually aligned. DNA sequences of all haplotypes were submitted to the European genetic database EMBL and are available under accession numbers AM180942-AM180948 for CO1 and AM181346-181348 for 16S.

A parsimony network was built with TCS (estimating gene genealogies version 1.13; TEMPLETON et al., 1992). The $F_{\mathrm{ST}}$ value (the genetic differentiation between any 2 subpopulations) was calculated by means of an AMOVA (EXCOFFIER et al., 1992) to determine the degree of genetic differentiation amongst the populations of $A$. torrentium (software Arlequin 2.0; SCHNEIDER et al., 1999). Genetic heterogeneity within populations was estimated as haplotype diversity $\left(h=1-\Sigma f_{i}^{2}\right.$; where $f_{i}$ is the frequency of the $i$ th haplotype).

\section{RESULTS}

15 sequences of the $16 \mathrm{~S}$ gene resulted in three different haplotypes. One of them (HT1) was found in all sequenced specimens from Germany (9) and Austria (1), irrespective of their belonging to the Rhine or Danube catchment. The second haplotype (HT2) was found in the three specimens from Slovenia and differs from HT1 in 7 transitions. The third haplotype (HT3) was characteristic of the two specimens from Bulgaria and differed from HT1 in 5 transitions and one transversion and from HT2 in 3 transitions and one transversion. HT1 is furthermore identical with the 16 S sequences from Genbank AF235984 and AJ242699 corresponding to the studies by CRANDALL et al. (2000) and LARGIADÈR et al. (2000), respectively, except that both of these sequences are shorter (492 and 448 basepairs) and they each include one deletion. This deletions are most likely sequencing / reading mistakes, because they are at the relative beginning (position 30 in AF235984) or end (position 12 in the complemented AJ242699) of the respective sequences and we assume that the sequences represent the same 16S mitochondrial haplotype from central Europe. The specimen corresponding to AJ242699 was from the Swiss locality Romanshorn (C. LARGIADÈR, personal communication) and the one from AF235984 probably from France, donated by F. GRANDJEAN. The third sequence available in Genbank AF337599 from GRANDJEAN et al., 2000a matches perfectly HT2 except for having an extra $A$ at the end (position 490) and being 511 basepairs long, and therefore must belong to a Slovenian population (see MACHINO, 1997), as confirmed by the author (F. GRANDJEAN, personal communication).

Due to the genetic homogeneity of $16 \mathrm{~S}$ in the German populations, we concentrated our sequencing efforts on the $\mathrm{CO} 1$ gene, which is generally known to be more variable. For this gene, a total of 50 sequences were obtained, of which 45 were from Germany, Switzerland and Austria and 5 belonged to the outgroups from Slovenia and Bulgaria. Within the in-group, only 3 variable positions out of 658 compared base pairs of COI were found resulting in five distinct haplotypes (Table I). Most noticeable was the prevalence of one most common haplotype, which was found in populations belonging to the Rhine as well as to the Danube catchment. The single museum specimen from the Wienerwald in eastern Austria had a transition in sequence position 435, which was only found once and could not be confirmed due to the lack of additional specimens from this population. The other two variable positions were transitions in sequence position 24 and 193 (in both cases $T$ instead of $C$ ), resulting in the three remaining haplotypes (Figure 1, Table I). The relative distances between all haplotypes from Germany, Switzerland and Austria never exceeded two transitions, while Slovenian animals differed from the most common haplotype in 3 positions and Bulgarian ones in 27 positions as revealed by the network constructed with TCS (Figure 1). Interestingly, the three haplotypes caused by transitions 
in position 24 and 193 were only found in the German Alps of the Allgäu and the directly neighbouring populations from the Haldensee in Tyrol, all of which belong to the Danube tributaries Lech and Wertach.

F-statistics were applied to test whether the accumulation of rare haplotypes in the Allgäu-Tyrolean Alps is an indication of significant population differences, resulting from the lack of gene flow, compared to the rest of Germany and Switzerland. The analysis of variance of 658 base pairs of $\mathrm{COI}$ between 22 Allgäu-Tyrol representatives on one hand and 22 from the rest of Germany and Switzerland ( 13 from Danube tributaries and 9 from Rhine tributaries) on the other hand, revealed a highly significant $(p<0.0001)$ genetic differentiation and a relatively high $F_{S T}-$ value of 0,671 . High genetic differentiation is indicated by values above 0,15 (WRIGHT, 1978). Accordingly, the haplotype diversity $(h)$ of the "Allgäu-Tyrol" population of 0.628 is relatively high when compared to the "rest of Germany-Swiss" population with a haplotype diversity of 0 , since the latter invariably consisted of the most common haplotype.

\section{DISCUSSION}

Our results combined with those of TRONTELJ et al. (2005) suggest that the genetic diversity of stone crayfish Austropotamobius torrentium in central Europe north of the Alps is greatly reduced compared to the genetic diversity south of the Alps and in the Balkans. This can be explained by a postglacial leading edge effect as proposed by HEWITT (1999), resulting in a genetic bottleneck during rapid recolonization of extensive areas in central Europe. TRONTELJ et al. (2005) indicate that "stone crayfish from many parts of the Danubian and Adriatic drainage in Slovenia, and the Southeastern Alps, along with populations from the upper Rhine drainage, all share the same, monophyletic origin" and postulate that "the numerous, genetically very similar haplotypes are no older than the second half of the Pleistocene". In their study, this includes one haplotype from France and Germany (APT_Breisgau), one from Luxembourg (APT_Rouderbaach) and 11 haplotypes from the "southeastern Alps and Slovenia" with populations from eastern Italy, southern Austria and Slovenia. The high haplotype diversity encountered by these authors for the southern slopes of the Alps is in contrast with the low haplotype diversity we generally found north of the Alps. However, a closer look reveals that our populations from the Alps (Allgäu-Tyrol), especially the highest areas around Haldensee (Austria) and Forggensee (Germany) (MACHINO \& FÜREDER, 1998), are the ones with an elevated haplotype diversity, while populations from the Danube Basin, Bavarian Forest and Rhine tributaries show high genetic similarity by sharing one single haplotype. This agrees with the findings of LARGIADÈR et al. (2002) who suggested for $A$. pallipes that the Alpine region harbours the highest diversity and supports the idea of TRONTELJ et al. (2005) that many populations in the Alps may have survived the final cycles of glaciation in nearby microrefugia.

Our COI haplotypes are not completely comparable with those of TRONTELJ et al. (2005), despite of using the same primer region, because their sequence alignment omitted the first 75 base pairs of the $\mathrm{COI}$ gene fragment. This area includes one of our three variable positions from German and Austrian populations (sequence position 24) and defines two different haplotypes in our network (Figure 1, Table I). Furthermore, the sequences submitted by TRONTELJ et al. (2005) to Genbank include at the end three bases belonging to the reverse primer HCO 2198. These should not have been included in the analysis. For instance, their very last nucleotide is always submitted as an " $A$ " (as in the FOLMER et al., 1994 primer sequence). However, all $A$. torrentium and A. pallipes sequences obtained so far beyond this region (unpublished results) clearly show that this position must be a "G" in this genus. 


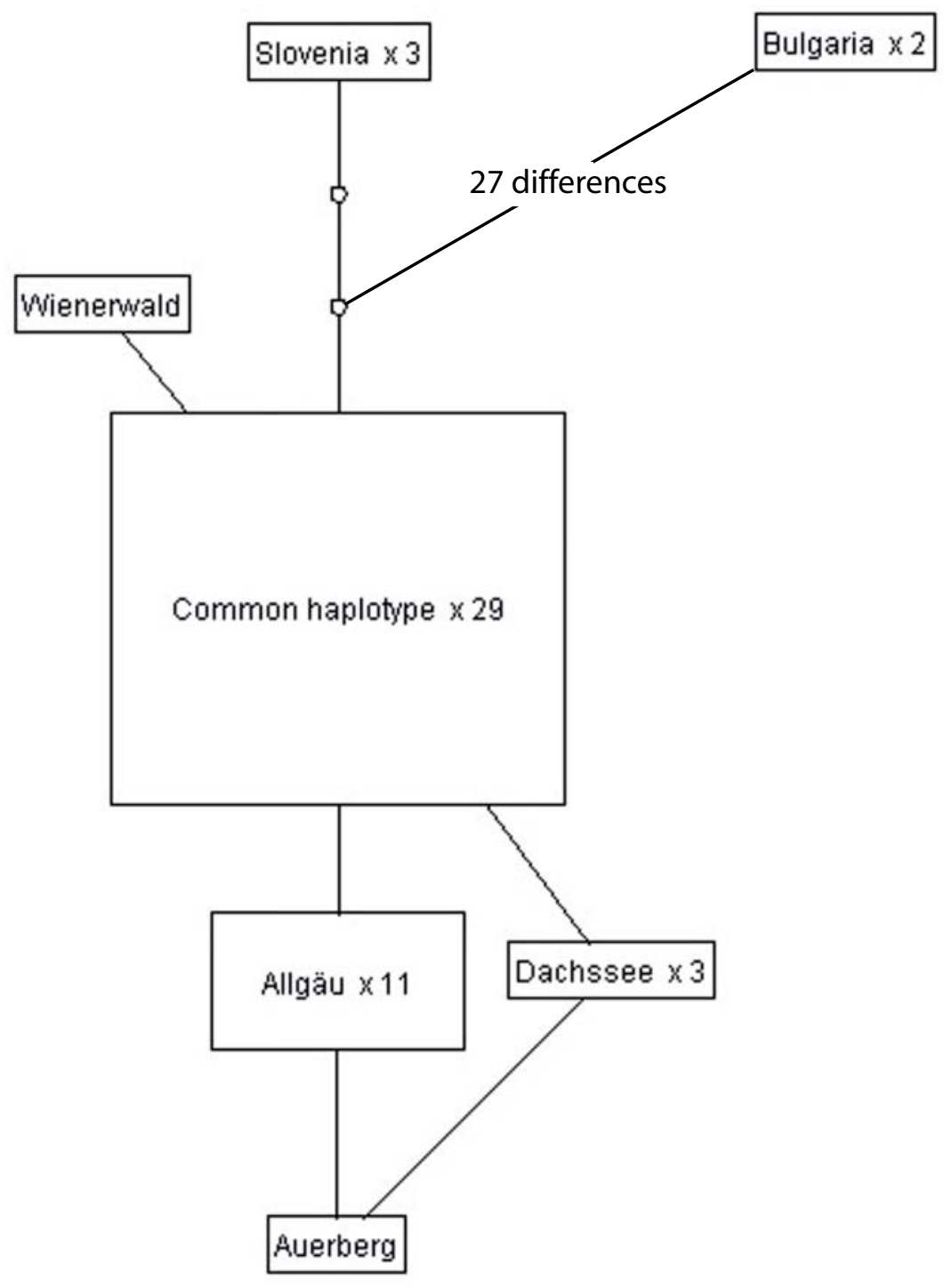

Figure 1

Minimum parsimonious spanning network constructed with TCS corresponding to 658 basepairs of $\mathrm{COI}$ and 50 individuals of the stone crayfish Austropotamobius torrentium. Each line represents one substitution; dots indicate "missing haplotypes". The size of each rectangle is representative for the frequency of the haplotypes. Auerberg and Dachssee are the names of two populations from the Allgäu. All analysed specimens from the Bavarian Forest (10) the Danube Basin (3), the Rhine Basin (9) in addition to 7 specimens from the Allgäu are gathered under the most common haplotype.

Figure 1

Réseau du minimum de parsimonie construit avec TCS à partir de 658 paires de bases du COI et $\mathbf{5 0}$ individus d'écrevisses des torrents Austropotamobius torrentium. Chaque ligne représente une substitution; les points indiquent des haplotypes manquants. La taille de chaque rectangle est représentative de la fréquence des haplotypes. Auerberg et Dachssee sont les noms de deux populations de l'Allgäu. Tous les spécimens analysés de la Forêt Bavaroise (10) du basin de Danube (3), du basin du Rhin (9) et 7 spécimens de l'Allgäu ont un haplotype commun. 


\section{Table I}

Distribution and nucleotide characterization of five haplotypes corresponding to 658 basepairs of $\mathrm{COI}$ from 45 individuals of German, Austrian and Swiss populations of Austropotamobius torrentium. Haplotype names correspond to those of Figure 1. Abbreviations: D, Germany; CH, Switzerland; A, Austria.

\section{Tableau I}

Distribution et caractérisation nucléotidique des cinq haplotypes correspondants aux 658 paires de bases du COI de 45 individus de populations d'Austropotamobius torrentium allemands, autrichiens et suisses. Les noms des haplotypes correspondent à ceux de la Figure 1. Abréviations : D, Allemagne ; $\mathrm{CH}$, Suisse ; A, Autriche.

\begin{tabular}{|c|c|c|c|c|c|c|c|}
\hline \multirow[b]{2}{*}{ Haplotype } & \multirow[b]{2}{*}{ \# Alps } & \multirow[b]{2}{*}{ \# Rest } & \multicolumn{3}{|c|}{$\begin{array}{l}\text { Nucleotide } \\
\text { position }\end{array}$} & \multirow[b]{2}{*}{ Distribution } & \multirow[b]{2}{*}{$\begin{array}{c}\text { Genetic } \\
\text { database \# }\end{array}$} \\
\hline & & & 24 & 193 & 435 & & \\
\hline Ht1: Most common & 7 & 22 & $\mathrm{C}$ & C & $\mathrm{C}$ & $\begin{array}{l}\text { D, CH: Rhine \& } \\
\text { Danube }\end{array}$ & AM180942 \\
\hline Ht2: Allgäu & 11 & 0 & $\mathrm{~T}$ & C & C & $\begin{array}{l}4 \text { Allgäu localities, } \\
\text { Haldensee (A) }\end{array}$ & AM180943 \\
\hline Ht3: Dachssee & 3 & 0 & $\mathrm{C}$ & $\mathrm{T}$ & C & 2 Allgäu localities & AM180944 \\
\hline Ht4: Auerberg & 1 & 0 & $\mathrm{~T}$ & $\mathrm{~T}$ & C & $\begin{array}{l}1 \text { Allgäu locality: } \\
\text { Auerberg }\end{array}$ & AM180945 \\
\hline Ht5: Wienerwald & 0 & 1 & $\mathrm{C}$ & C & $\mathrm{T}$ & $\begin{array}{l}\text { Wienerwald (eastern } \\
\text { Austria) }\end{array}$ & AM180946 \\
\hline
\end{tabular}

If for comparative reasons we do not consider the first 75 basepairs of our alignment, a most common haplotype would be present in 40 specimens from Rhine and Danube and four specimens from the Allgäu would remain as a second haplotype (based only on sequence position 193). The most common haplotype would be identical with APT_Breisgau (Genbank AY667141) from TRONTELJ et al. (2005), who obtained this haplotype in 3 individuals from the Rhine Basin (France and Germany), while the second haplotype from the Allgäu would be identical to TRONTELJ et al., APT_Rouderbaach (Genbank AY667143) from Luxembourg (Rhine Basin), which shares the transition at position 193. This is surprising, because we never encountered a haplotype with this transition in a population outside of Allgäu-Tyrol (see Table I). More specimens from Luxembourg and neighbouring Rhine populations should therefore be analysed in the future to test the frequency of this haplotype and to determine whether the Rouderbaach has an atypical haplotype composition that may have been caused by human-mediated translocation. Our haplotype from Slovenian specimens is identical to TRONTELJ et al., haplotype APT_CentrSI (Genbank AY667127) from five Slovenian populations around Ljubljana and Logatec and our haplotype from Bulgarian specimens only differs from TRONTELJ et al., haplotype APT_Koursovit (Genbank AY667134) from northern Greece in one transition, which is not surprising, because both localities form part of the Struma/ Strimón catchment.

Management strategies are often designed to maintain maximum levels of genetic diversity within populations. The rationale of this approach is based on the assumption that populations with high levels of genetic variation should be able to better cope with 
environmental changes. Therefore, genetically similar populations are often treated as a single population for management purposes (e.g. VRIJENHOEK et al., 1985) and genetically differentiated populations are suggested as candidates for special management consideration to prevent the loss of unique genetic variants (DOLE \& SUN, 1992). In our case, this would mean that for the protection of $A$. torrentium as a red list crayfish species in Germany (BINOT et al., 1998), it would be reasonable to give highest priority to the populations from the Bavarian Alps, since they seem to harbour all the genetic diversity also present in the other populations, at least considering a short region of the mitochondrial DNA. For confirmation of these results and the consequent implementation of conservation measurements, it will be useful to study genetic diversity of the same geographic range with nuclear markers, especially microsatellites. This method should also render higher overall variability and thus allow a better resolution of the underlying genetic structure and shed light on the historical events during postglacial colonization of this crayfish species.

\section{ACKNOWLEDGEMENTS}

We would like to thank the organizing committee of the Craynet Meeting 2005 in Florence and especially Francesca Gherardi for the invitation, and participants of the meeting for their feedback. Swiss material was obtained thanks to Carlo Largiadèr (Switzerland), Austrian one during the excursion of Craynet 2004 organized by Leo Füreder to Haldensee (Austria) and material from German Rhine tributaries during field trips with Klaus Duffner (Freiburg) and Dirk Brandis (Heidelberg). We thank Carlo Largiadèr and Frédéric Grandjean for personal information concerning their 165 sequences and for advice. We are indebted to Silke Reuschel for her continuing help in the lab and with the statistical analyses. Nathalie Stroeymeyt kindly translated the abstract into French. Valérie Maniglier proved to be a great editor and two referees made useful comments. Last not least, we thank all the Bavarian local governments for permits and co-operation.

\section{REFERENCES}

ALBRECHT H., 1983. Besiedlungsgeschichte und ursprünglich holozäne Verbreitung der europäischen Flusskrebse. Spixiana, 6, 61-67.

BINOT M., BLESS R., BOYE P., GRUTTKE H., PRETSCHER P., 1998. Rote Liste gefährdeter Tiere Deutschlands. Bundesamt für Naturschutz, $435 \mathrm{p}$.

CRANDALL K.A., HARRIS D.J., FETZNER J.W. JR., 2000. The monophyletic origin of freshwater crayfish estimated from nuclear and mitochondrial DNA sequences. Proc. R. Soc. Lond., B, Biol. Sci., 267, 1679-1686.

DOLE J.A., SUN M., 1992. Impact of hybridization on a threatened trout of the southwestern United States. Conserv. Biol., 6, 355-364.

EXCOFFIER L., SMOUSE P.E., QUATTRO J.M., 1992. Analysis of molecular variance inferred from metric distances among DNA haplotypes: application to human mitochondrial DNA restriction data. Genetics, 131, 491-497.

FOLMER O., BLACK M., HOEH W., LUTZ R., VRIJENHOEK R., 1994. DNA primers for amplification of mitochondrial cytochrome $\mathrm{c}$ oxidase subunit I from diverse metazoan invertebrates. Mol. Mar. Biol. Technol., 3, 294-299.

FRATINI S., ZACCARA S., BARBARESI S., GRANDJEAN F., SOUTY-GROSSET C., CROSA G., GHERARDI F., 2005. Phylogeography of the threatened crayfish (genus Austropotamobius) in Italy: implications for its taxonomy and conservation. Heredity, 94, 108-118. 
GOUIN N., GRANDJEAN F., BOUCHON D., REYNOLDS J.D., SOUTY-GROSSET C., 2001. Population genetic structure of the endangered freshwater crayfish Austropotamobius pallipes, assessed using RAPD markers. Heredity 87, 80-87.

GRANDJEAN F., SOUTY-GROSSET C., 2000. Mitochondrial DNA variation and population genetic structure of the white-clawed crayfish, Austropotamobius pallipes pallipes. Conservation Genetics, 1, 309-319.

GRANDJEAN F., HARRIS D.J., SOUTY-GROSET C., CRANDALL K.A., 2000a. Systematics of the European endangered crayfish species Austropotamobius pallipes (Decapoda: Astacidae). J. Crust. Biol., 20, 522-529.

GRANDJEAN F., GOUIN N., SOUTY-GROSET C., DIÉGUEZ-URIBEONDO J., 2000b. Drastic bottlenecks in the endangered crayfish species Austropotamobius pallipes in Spain and implications for its colonization history. Heredity, 86, 431-438.

GRANDJEAN F., FRELON-RAIMOND M., SOUTY-GROSSET C., 2002a. Compilation of molecular data for the phylogeny of the genus Austropotamobius: one species or several?. Bull. Fr. Pêche Piscic., 75, 671-680.

GRANDJEAN F., BOUCHON D., SOUTY-GROSSET C., 2002b. Systematics of the European endangered crayfish species Austropotamobius pallipes (Decapoda: Astacidae) with a re-examination of the status of Austropotamobius berndhauseri. Crust J.. Biol., 22, 677-681.

HEWITT G.M., 1999. Post-glacial recolonization of European biota. Biol. J. Linn. Soc., 68, 87-112.

HUBER M.G.J., SCHUBART C.D., 2004 Genetic analysis of the stone crayfish (Austropotamobius torrentium) in Germany, with emphasis on the local distribution around Regensburg and the impact of alien crayfish species. Abstract in "Craynet $3^{\text {rd }}$ Thematic Meeting, Innsbruck" abstract book.

HUBER M.G.J., SCHUBART C.D., 2005. Distribution and reproductve biology of Austropotamobius torrentium in Bavaria and documentation of a contact zone with the alien crayfish Pacifastacus leniusculus. Bull. Fr. Pêche Piscic., 376, 377, 759-776.

LARGIADÈR C.R., HERGER F., LÖRTSCHER M., SCHOLL A., 2000. Assessment of natural and artificial propagation of the white-clawed crayfish (Austropotamobius pallipes species complex) in the Alpine region with nuclear and mitochondrial markers. Mol. Ecol., 9, 25-37.

MACHINO Y., 1997. Crayfish of the Upper Soca and Upper Sava Rivers, Slovenia. Bull. Fr. Pêche Piscic., 347, 721-729.

MACHINO Y. and FÜREDER L., 1998. Der Steinkrebs Austropotamobius torrentium (Schrank, 1803) in Haldensee (Tirol, Österreich) und weitere Nachweise von Flußkrebsen in hochgelegenen Gewässern. Ber. Nat. med. Verein Innsbruck, 85, 223-229.

SCHNEIDER S., ROESSLI D., EXCOFFIER L., 1999. Arlequin ver. 2.0: software for population genetic data analysis. Genetics and Biometry Laboratory, University of Geneva, Geneva, Switzerland.

SCHUBART C.D, CUESTA J.A., FELDER D.L., 2002. Glyptograpsidae, a new brachyuran family from central america: Larval and adult morphology, and a molecular phylogeny of the Grapsoidea. J. Crust. Biol., 22, 28-44. 
TEMPLETON A.R., CRANDALL K.A., SING C.F., 1992. A cladistic analysis of phenotypic associations with haplotypes inferred from restriction endonuclease mapping and DNA sequence data. III. Cladogramm estimation. Genetics, 132, 619-633.

TRONTELJ P., Y. MACHINO, SKET B., 2005. Phylogenetic and phylogeographic relationships in the crayfish genus Austropotamobius inferred from mitochondrial COI gene sequences. Mol. Phylogen. Evol., 34, 212-226.

VRIJENHOEK R.C., DOUGLAS M.E., MEFFE G.K., 1985. Conservation genetics of endangered fish populations in Arizona. Science, 229, 400-402.

WRIGHT S., 1978. Variability within and among natural populations. Chicago, University of Chicago Press. Evolution and the Genetics of Populations. 